\title{
H
}

Volume 17 Issue 1 Year: 2020

\section{The process of institutionalized women's movement in Turkey}

\section{Türkiye'de kadın hareketinin kurumsallaşma süreci}

\author{
Ceyda Kuloğlu ${ }^{1}$
}

\begin{abstract}
1980s are the period that women's movement in Turkey gained momentum relative to the previous years. Although the women's movement and its institutionalization period were a near-perfect though in theory, it still has an importance to review the historical background of the women's movement in Turkey for the contemporary and future studies. The reason for this is that most of the studies can remain in the descriptive study dimension due to the fact that they do not refer to the previous period of women's movement and that they do not have the knowledge of their roots. The purpose of this review work in this context is to put forth the historical roots of the institutionalization of the women's movement in Turkey in order to shed light on the contemporary studies by using the historical background and to develop new strategies for contemporary policy with the help of the past experiences.
\end{abstract}

In explaining the development of feminism in Turkey, different periodization studies were used. Some of them are: According to Sirman (1989); (a) The Ottoman Period (b) The first periods of the Republic (c) 1980s are 3 periods. According to Tekeli (1986); (a) Before Tanzimat (b) Tanzimat Period (c) The first years of the Republic and the period of one-party regime (d) From 1950 to the present four periods. According to Nizam (1993); (a) Before the War of Independence (b) After the War of

\section{Özet}

1980'ler Türkiye'deki kadın hareketinin önceki y1llara göre ivme kazandığ1 dönemdir. Her ne kadar kadın hareketi ve kurumsallaşma süresi teoride mükemmele yakın olsa da çağdaş ve gelecekteki çalışmalar için Türkiye'deki kadın hareketinin tarihsel arka planını gözden geçirmek hala önemlidir. Bunun nedeni, çalışmaların çoğunun, kadın hareketinin önceki dönemine değinmedikleri ve kökleri hakkında bilgi sahibi olmadıkları için tanımlayıcı çalışma boyutunda kalabilmeleridir. Bu bağlamda yapılan bu derleme çalışmasının amacı, tarihsel arka planı kullanarak çağdaş çalışmalara 1şık tutmak ve çağdaş politika için yeni stratejiler geliştirmek amaciyla Türkiye'deki kadın hareketinin kurumsallaşmasının tarihsel kökenlerini ortaya koymaktır.

Türkiye'de feminizmin gelişimini açılklarken farklı dönemselleştirme çalışmaları kullanılmıştır. Bunlardan bazıları: Sirman'a göre (1989); (a) Osmanlı Dönemi (b) Cumhuriyet'in ilk dönemleri (c) 1980'ler 3 dönemdir. Tekeli'ye (1986) göre; (a) Tanzimat Öncesi (b) Tanzimat Dönemi (c) Cumhuriyet'in ilk y1lları ve tek parti rejimi dönemi (d) 1950'den günümüze kadar olan dört dönem. Nizam'a (1993) göre; (a) Kurtuluş Savaşı'ndan önce (b) Kurtuluş Savaşi'ndan sonra (c) 1980'den sonra.

Bu çalışmada Türkiye'deki feminist hareketin gelişimi kadınların toplumdaki konumuna göre farklılaşmıştır. Bu bağlamda, çok tartışmalı bir dönüm noktası olarak kavramsallaştırılan beş

1 Dr. Öğr. Üyesi, Başkent Üniversitesi, Fen-Edebiyat Fakültesi, Sosyoloji Bölümü, ceyda.kuloglu@gmail.com (iD) Orcid ID: https://orcid.org/0000-0002-0170-9439 
Kuloğlu, C. (2020). Türkiye'de kadın hareketinin kurumsallaşma süreci. Journal of Human Sciences, 17(1), $324-339$. doi:10.14687/ihs.v17i1.5949

Independence (c) After 1980.

In this study, the development of the feminist movement in Turkey has been differentiated according to the position of women in society. In this context, five chapters have been formed from the pre-Islamic period, which is conceptualized as a very controversial milestone.

1. The Position of Women in the Pre-Islamic Society

2. The Position of Women after Islam and in Ottoman Empire

3. The Position of Women in Society in the Republican Period

4. The Position of Women in the 1980s and $1990 \mathrm{~s}$

5. Women's Movement in Turkey in 2000s

Keywords: Women's movement, feminism, institutionalism, gender equality, patriarchal system.

(Extended English summary is at the end of this document) bölüm oluşturulmuştur:

1. Kadınların İslam Öncesi Toplumdaki Konumu

2. Kadınların İslam Sonrası ve Osmanlı İmparatorluğu'nda Konumu

3. Cumhuriyet Döneminde Kadınların

Toplumdaki Yeri

4. 1980'ler ve 1990'larda Kadınların Konumu

5. 2000'li Yıllarda Türkiye'de Kadın Hareketi

Anahtar Kelimeler: Kadın hareketi, feminizm, kurumsallaşma, toplumsal cinsiyet eşitliği, ataerkil düzen.

\section{Giriş}

1980'ler Türkiye'deki kadın hareketinin önceki yıllara göre ivme kazandığı dönemdir. Her ne kadar kadın hareketi ve kurumsallaşma süreci mükemmele yakın olsa da, günümüzdeki ve gelecekteki çalışmalar için Türkiye'deki kadın hareketinin tarihsel arka planını gözden geçirmek hala önemlidir. Bunun nedeni, çalışmaların çoğunun, kadın hareketinin önceki dönemine değinmedikleri ve kökleri hakkında bilgi sahibi olmadıkları için betimleyici çalışma boyutunda kalabilmeleridir. Bunun yanı sıra kadın hareketinin Türkiye'de 2000lerden itibaren bir nevi duraklama döneminde olduğunu iddia etmek yanlış olmaz. Bu bağlamda yapılan bu derleme çalışmasının amacı, tarihsel arka planı kullanarak güncel çalışmalara ışık tutmak ve güncel feminist politika için yeni stratejiler geliştirmek amacıyla Türkiye'deki kadın hareketinin kurumsallaşmasının tarihsel kökenlerini ortaya koymaktır.

Türkiye'deki kadın hareketinin gelişimini açılarken farklı dönemselleştirmeler kullanılmıştır. Bunlardan bazıları, Sirman (1989)'a göre, (a) Osmanlı Dönemi (b) Cumhuriyetin ilk dönemleri (c) 1980'ler şeklinde 3 dönemdir. Tekeli (1986)'e göre, (a) Tanzimat'tan öncesi (b) Tanzimat Dönemi (c) Cumhuriyetin ilk y1lları ve tek partili rejim zamanı (d) 1950'den günümüze şeklinde 4 dönemdir. Son olarak Nizam (1993)'a göre ise, (a) Kurtuluş savaşı öncesi (b) Kurtuluş savaşı sonrası (c) 1980 sonrası şeklinde 3 dönemdir.

Farklı dönemselleştirmeler olmasına rağmen bu konuda çalışanların üzerinde genellikle fikir birliğine vardıkları nokta Türkiye'de kadın hareketlerinin Cumhuriyetin ilanından ve/veya Kemalist reformlardan çok önce başlamış olduğudur. Türkiye'de kadın hareketinin gelişim süreci bu çalışmada kadınların toplumdaki konumuna göre farklılaştırılmıştır. Bu bağlamda, bütün bir arka planı göstermek gayreti ile İslamiyet öncesinden günümüze kadar olan bir dönemselleştirme yapılmış ve kadın hareketinin gelişim süreci Türkiye'de beş bölümle incelenmiştir:

1. İslamiyet Öncesindeki Toplumda Kadınların Konumu

2. Kadınların İslamiyet Sonrasında ve Osmanlı İmparatorluğu'nda Konumu

3. Cumhuriyet Döneminde Kadınların Konumu 
4. 1980’ler ve 1990’larda Kadınların Konumu

5. 2000'li yıllarda Türkiye'de Kadın Hareketi

Feminizmin ve kadın hareketinin Türkiye'de gelişimine bakmadan önce "kadın hareketi" kavramından ne anlaşıldığını vurgulamak yerinde olur. Arat (1994)'e göre kadın hareketi, kendilerini feminist olarak nitelendiren kadınların kolektif hareketidir. Kadın hareketinin başlıca amacı, kadın olmaktan kaynaklanan, kimi zaman bilinçli olarak kimi zamansa istemeyerek, sınırlanmış firsatlarını genişletmektir. Kadın hareketinin kurumsallaşması ise, "kadın ve erkek arasında eşitsiz uygulamaların ortadan kaldırılması için gerekli salt düzenlemelerin yapılması, devlet tarafindan kadınların özel alandan kamusal alana geçişlerini kolaylaştırıcı önlemlerin alınması, kadınların toplumsal, ekonomik ve siyasal haklarını erkeklerle eşit biçimde kullanmalarının sağlanması için devletin gerekli politikaları oluşturması ve bütçe tahsislerinin olumlu bir şekilde yeniden yapılandırılması da dahil olmak üzere tüm uygulamaları kapsamaktadır”" (Çilingiroğlu 2001).

\section{İslamiyet Öncesindeki Toplumda Kadınların Konumu}

İslamiyet öncesinde kadınların Türk topluluklarında toplumsal yaşantının dışında tutulmadığ1 tek eşli evlilik kurallarının geçerli olduğu ve aile içerisinde kadının eşit haklara sahip olduğu kaynaklardan anlaşılmaktadır (Tekeli 1982: 192-193). İslamiyet’ten önce Türk kadınıyla ilgili bilgiler Oğuz Destanı'nda yer alan aile düzenlemesinin incelenmesiyle ortaya çıkmaktadır. Oğuz Destanı’ndan aile düzeninin “baba ailesi” olduğu anlaşılmaktadır. Ŏguz'daki anlamıyla baba ailesi babanın eşi ve çocukları üzerinde törelerle sınırları çizilmiş bir yetkiye sahip olduğu kadının erkeğine görüşlerini rahatça açabildiği bir anlamda demokratik bir düzendir (Süllü 1988: 56).

Ziya Gökalp’in (1996) “Türkçülüğün Esasları” kitabında belirttiği üzere, eski Türkler hem demokrat hem de eşitlikçilerdi. Eski Türklerce Şamanizm kadındaki kutsal güce dayanmaktaydı. Türk şamanları sihir kuvvetiyle harikalar gösterebilmek için kendilerini kadınlara benzetmek zorundaydılar. Buna karşıllk toyonizm dini de erkeğin kutsal kut ve kuvvetinde görünürdü. Toyonizm ile Şamanizmin değerce eşit olması hukukça kadın ve erkeğin eşit tanınmasına neden olmuştu. Her işin hem Toyonizm'e hem de Şamanizm'e dayanması gerektiğinde her işte kadın ve erkek birlikte bulunmak durumundaydi. Halkın sorumluluğu hakan ve hatunda ortak bulunurdu ve bir emrin kabul edilmesi için "hakan ve hatun buyuruyor ki" sözü ile başlaması zorunluydu aksi takdirde kimse bu emre itaat etmezdi. Ayrıca eski Türklerde eş (karı) yalnızca bir tane olabilirdi. Emperyalizm devirlerinde bu eşten başka kuma adı altında başka illerde mensup odalıkları da bulunabilirdi fakat Türk töresi kumaları resmen eş tanımazdı. Binicilik, silahşörlük, kahramanlık Türk erkekleri kadar Türk kadınlarında da vardı. Kadınlar doğrudan doğruya hükümdar, kale muhafızı, vali ve elçi olabilirlerdi. Sıradan ailelerde ev ortak olarak karıly kocanın ikisine aitti. Erkekler her zaman karısına sayg1 gösterir, onu arabaya bindirerek kendisi yolda yürürdü. Kısacası, eski Türklerde kadın erkek eşitliği en önemli ilkelerden biriydi. Kadınlar malları kullanma hakkına sahip oldukları gibi dirliklere de sahip olabilirlerdi. Ayrıca eski Türklerde ana soyuyla baba soyu değerce birbirine eşittir (Gökalp 1996: 165-167).

Eski Türklerde kadınlara toplum içinde oldukça fazla değer verildiği görülmektedir. Her alanda kadın erkek eşitliğini görmek mümkündür. At binmek, kılıç kullanmak, tarım ve hayvancılık gibi toplumsal yaşamın her alanında eşit koşullarda çalışma ve hak sahibi olma durumları vardır (Yapar Gönenç 2012: 72). Türk kadının değerinin at binmek, k1lıç kullanmak, ok atmak, düşmana akın etmekle ölçüldügünün en güzel göstergelerinden biri de Dede Korkut Hikayeleridir. Oğuzların yaşamını içeren bu hikayelerde toplumda en geçerli değerin kahramanlık olduğu anlaşılmaktadır. Göçebeliğin güç koşullarının gerektirdiği kahramanlık özelliği kadınlar için de geçerlidir. Hikayelerde yer alan "kalabalık korkutur" atasözü kadının doğurganlığı nedeniyle değerli olduğu bir dönemin görüşünü yansitır. Özellikle de anaya verilen değer bu hikayelerde aç1kça belirtilmektedir (Arat 1986: 75-81). 
Kuloğlu, C. (2020). Türkiye'de kadın hareketinin kurumsallaşma süreci. Journal of Human Sciences, 17(1), $324-339$. doi:10.14687/ihs.v17i1.5949

\section{Kadınların İslamiyet Sonrasında ve Osmanlı İmparatorluğu'nda Konumu}

"Türk toplumunda çeşitli dönemler kadına verilen önem ve kadının toplum içindeki konumu değişiklikler göstermiştir. İslamiyet’in kabulünden önce Türk toplumunda kadın erkekle eşit hak ve konuma sahipken İslamiyet'in benimsenmesinden sonra İslam dininin ve özellikle Arap kültürünün etkisiyle kadın 'ikinci sınıf vatandaş’ konumuna indirgenmiştir” (Yapar Gönenç 2012: 71).

İslamiyet'in kabulünden sonra da aşiret geleneklerinin devam ettiği ileri sürülmektedir. Türklerin İslamiyet'i X. yüzyılda kabul etmelerine karşın XIV. yüzyılda kadınlara verilen değerin anlatıldığ1 Dede Korkut Hikayeleri bu görüşün göstergesi sayılabilir. İslam dininin, Osmanlı Devleti’nin kuruluş aşamalarında, kadını toplumsal yaşantı dışında tutulacak biçimde yorumlandığı savunulmaktadır (Tekeli 1982: 193). Selçuklu kadının da İslamiyet’i benimsemesine karşın özgür yaşantısını yitirmediği bilimsel çalışma ya da hayır işi ve sanat çalışmalarında yer alabildiği anlaş1lmaktadır (Alkan 1981: 9).

Buna karşılık İslamiyet'in benimsenmesi sırasındaki Araplarla ilişkilerin Türk boylarının yaşam biçimlerini değiştirdiği, Kaşgarlı Mahmud'un Divan'ında yer almaktadır. Kaşgarlı Mahmud bu yapıtında Türklerin İslamiyet'i kabul etmesiyle kendi geçmişlerini unutacak duruma geldikleri Araplardan çok etkilendiklerini belirtmiştir. Bu yeni kültürden kadınların etkilenmesi ise kadınların gerek toplumsal gerek yasal haklarının kisıtlanması şeklinde olmuştur (Arat 1986: 96). XVI. yüzyıldan itibaren teokratik devlet yapısına bürünen Osmanlı Devleti’nde saray, yönetici sinıflar, ulema, İslamiyet'in kadını baskı altına almasını pekiştirici rol oynamışlardır. İstanbul'un alınmasından sonra Osmanlı'ların Bizans Devlet yapisindan etkilenmesiyle kadın "hareme" kapatılmıs ve toplum yaşantısının dışına itilmiştir. Ancak kentlerde yaşayan kadınlar hareme kapatılırken asıl üretimin yapıldığı kırsal alanda kadının üretim sürecinin dışına çıkmadığı görülmektedir (Tekeli 1982: 192-195).

Kentsel alanda ise üretimden kopmuş kadınlar kamu yaşamından tamamen soyutlanmış olarak ev içi işlerle uğraşarak bir anlamda kendi haremlerini oluşturmaktadırlar. Bu kadınlara sokağa çıkma ve giysilerinin belirlenmesi gibi sınırlamalar getirilmiş, toplum dışına itilmişlerdir. Batı'da kadınların siyasal ve sosyal hak savaşını başlattı̆̆ı bu dönemlerde Türk kadını değil hak savaşı vermek, sokağa çıkmak ve dilediğince giyinmek haklarından bile yoksundur. Sübyan okulu denilen dokuz yaşına kadar çocukların eğitim gördüğü okulların ötesinde eğitim görmesine hak tanınmamaktadır. Bu okullardaki eğitim ise din ilkeleri üzerine kurulmaktadır. Çok eşliliğe izin veren şeriat yasaları ve boşanma hakkının kocaya tanınması kadını tamamen kısıtlanmış bir duruma sokmaktadır. Azınlık gruplarından olan kadınların bazı alanlarda çalıştıkları saptanmasına karşın çalışan hiçbir Osmanlı kadınının izine rastlanmamaktadır (Tekeli 1982: 195).

Evin işlerini yürütüp çocuklarının bakımıyla yükümlü olan kadın geleneksel aile içinde bu yükümlülükleriyle sınırlı bir değere sahiptir. Fakat gerek aile içindeki gerekse toplumdaki konumu üretim işleviyle orantılı değildir. Kadının aile içindeki konumu çocuklarının sayısı ve yaşlılık ile yükselmektedir. Kırsal kesimin dışında üretimde yer almamasına karşın evlilik yoluyla bir aileden diğerine geçen kadın bu geçiş karşıllğı ödenen başlıkla meta haline gelmektedir (Ortaylı 1984: 8081). Toplu yaşamın tüm eksenini cinslerin ayrıllğ̆ üzerine inşa etmiş olan İslam toplumsal barış1 tehdit eden en önemli öge olarak kadınların temsil ettikleri "fitneyi” görmektedir. Fitne hem baştan çıkarma ve fesat hem de çekicilik ve isyandır. Erkekler kadının bu çekiciliğine kapıldıkları vakit Allah'ın iradesine karşı ayaklanmış sayılırlar. İslamiyet cinselliği etkin bir tehlike olarak görmekte bu yüzden cinselliğin sıkı bir denetime tabi tutulması gerektiğinin altını çizmektedir. Bu nedenle cinslerin yaşam alanları çok keskin hatlarla ayrılmıştır. Buna göre kamusal alan erkeğin, özel alan kadının yaşamlarını geçirdikleri yer olmaktadır (Abadan Unat 1998: 323).

Osmanlı Devleti'nin İslam hukuku Şeriat ile yönetilmesi kadınların toplumdaki ikinci sınıf olma durumlarını pekiştirmiştir. Çünkü Berktay'ın (1994) belirttiği gibi şeriatta kadınlar doğal olarak erkeklere göre aşağı konumdadır. Bu toplumsal yap1 19. yüzyılın ikinci yarısında Mısır’da olduğu gibi Osmanlı İmparatorluğu'nda da değişim isteklerine yol açmıştır. Batılılaşma ve modernleşme isteklerinin ilk ifade edilmeye başlandığı anda kadın erkek ilişkileri de bu tartışmanın 
kapsamına girmiştir. İşin ilginç yanı bu tartışmanın önce erkekler tarafından başlatılmasıdır (Abadan Unat 1998: 324). Dönemin erkek romancılarının da belirttiği gibi erkek reformcular Batı'dan esinlenmiş demokratik ideolojilerin de etkisiyle, artık görücü usulüyle evlenmek istemiyorlar, evliliklerinde karşılıklı dostluk ve sevgi ilişkisi arıyorlar her dediklerine boyun eğecek kadından çok eğitimli ve konuşabilir "eşler" istiyorlardı. Bu nedenle de cinslerin tecridi ve kaç-göç uygulamasına karşı çıkıyorlardı. Bu basitçe Batı'ya öykünmenin bir ifadesi değil aile içindeki ataerkil baskıya karşı erkeklerin başkaldırışıydı. Aynı erkekler artık mutlak monarkın (Sultan'ın) uyrukları olmak istemiyor ve anayasal bir yönetim altında yurttaş olmak istiyorlardı (Berktay 1998: 21).

Bu tartışmaya 19. yüzyılın sonuna doğru Osmanlı toplumunun eğitilmiş, üst sınıfa mensup kadın yazarlar da katılmıslardı (Abadan Unat 1998: 324). Tanzimat dönemine gelinceye dek Avrupa'da görülen bireysel ve örgütlenmiş kadın hakları savunmaları görülmemektedir. Kösem Sultan, Hürrem Sultan gibi kadınların adları ünlü olmakla birlikte bunların yaptığı kadın hakları savunuculuğu olmamış, sadece devlet politikasına karışma girişimleri ve becerileri tarihe geçmelerini sağlamıştır (Süllü 1988: 62).

Ne zaman ki Tanzimat hareketi Osmanlı Devleti içinde gelişmeye başlamıştır, kadınlar da bu Batılılaşma hareketi ile birlikte siyasi ve toplumsal hak taleplerine başlamışırı. Kadınlar için hukuk, siyaset, eğitim, çalışma, din ve bilim alanlarında hak taleplerinin bu dönemde başladığı söylenebilir (Yapar Gönenç 2012: 74). Tanzimat dönemindeki değişikliklerin yalnızca moda, günlük yaşam, tüketim kalıplarındaki değişim, yabancı dil öğrenmek, piyano çalmak gibi yeni uğraşlarla sınırlı kalmadığı görülmektedir. Osmanlı ülkelerinde 19. yüzyılda tarımda, eğitimde, görülen yapisal değişimler dünyadaki iletişim ve teknolojideki devrime koşut olarak yaşanmaya başlamıştır. Bu gelişmelerin Osmanlı topraklarına yansıması kent kadar kırsal kesimde de kendini göstermiştir (Ortaylı 1984: 85).

1839'da yayınlanan Gülhane Hatt-1 Hümayunu ${ }^{2}$ din, ırk ve cins ayrımı gözetmeksizin bireysel hakları güvence altına almaya ilk adım olarak görülmektedir. Gülhane Hatt-1 Hümayunu'nun getirdiği reformlar kadınların kurtuluşu hareketinin başlangıcını oluşturmuştur. Bu dönemde okulların Batı'dan örnek alınarak düzenlenmesi, getirilen yeni hukuk düzenlemeleri, Avrupa'daki ideolojik akımların yayılması, basının gelişmesi, yabancı dilin önem kazanması sonucu batıda olup biteni öğrenmesi yeni bir kültürün doğmasına neden olmuştur. Bu da sonuçta kadının durumunun düzeltilmesi için atılan adımlara destek sağlamıştır. Fakat bu düzenlemelerin belli kesimden kadınları etkilendiğini de belirtmek gerekmektedir (Arat 1986: 102).

Tanzimat kadın haklarında köklü değișmeler getirmemișse de bu konuda görece ilerlemeler sağlayacak bazı düzenlemelerle kadının durumunun tartışma konusu edilebildiği anlaşılmaktadır (Süllü 1988: 63). Tanzimat döneminin getirdiği sosyo-kültürel değişim hiç değilse üst ve orta tabaka kadınının toplumsal yaşama katılımını hazırlayan bir dönem olmuştur. Düşünür ve yazarların geleneksel aile yapısını ve geleneksel evlenme biçimini eleştiren kampanyalar açıp, yazılar yazdıkları görülmektedir (Tekeli 1982: 196). Abdülhamit döneminin katı Pan-İslamist yönetimine karşın kadınlar seslerini yükseltmeye başlamış, basın ve yayın sansürlerine karşı gelişme göstermiş ve kadın okuyucu sayısı artmıştır (Arat 1986: 103-104). 1880’lerde Rusya Müslümanlarından bir grup kadının çıkardığı Alem-i Nisvan adlı kadın gazetesi feminist çabanın ilk ürünlerinden sayılabilmektedir (Ortaylı 1984: 86). 1868 yılında yayınlanmaya başlanan Terakki Gazetesi kadının geri bırakılmasına ilişkin yazılara yer vermektedir. Bu gazete daha sonra Muhadderat adında kadınlar için bir gazete çıkarmıştır. Bu gazeteyi Vakit, Aile, Ayine, Şukifezar, İnsaniyet, Parça Bohçası gibi gazeteler izlemiştir. Hanımlara Mahsus Gazete hemen hemen tümüyle kadınlardan oluşan bir kadroyla en uzun süreli gazete olmuştur (Tekeli 1982: 196-197).

\footnotetext{
2 “1839’da Mustafa Reşid Paşa tarafindan Gülhane’de okunan ve Tanzimat devrini başlattığı için Tanzimat Fermanı da denilen Sultan Abdülmecid'in fermanı”. https://islamansiklopedisi.org.tr/gulhane-hatt-i-humayunu (Erişim tarihi 08.01.2020).
} 
Bu yayınların çıtı̆̆ı yıllar batıda kadınların (suffragetler) siyasal hak mücadelelerini yoğun olarak yaşadığı, feminist isteklerin belirlenmeye başladığı dönemler olmasına karşın Osmanlı kadınından bu tür istekler gelmemektedir. Bütün yayınlarda kadın için geçerli ilkeler, toplumsal cinsiyet rollerine uygun olarak, iyi ana, iyi eş ve iyi Müslüman olmaktır (Arat 1986: 104). Dönemin en ünlü kadın yazarlarından Fatma Aliye Hanım'ın yazdığı Nisvan-1 İslam adlı kitap Osmanlı toplumunda kadının durumunu sorguladığı, incelediği ve çözümler önerdiği bir kitaptır (Arat 1986: 107).

Tıpkı ikinci dalga feminizmin eleştiri konusu olduğu gibi, Türkiye'deki bu kadın hareketine dair gelişimler belli bir sınıfı konu alması sebebiyle eleştirilmiş ve henüz daha farklılıklara ve farklı kadın deneyimlerine değer verildiği zamanlara gelinmemişti. Abadan Unat (1979: 17) bunu kastederek, yapılan yayınların yalnızca üst sosyo-ekonomik düzeyden kadınların dikkatini çektiğini ve Osmanlı toplumu içindeki kadın hareketine gerçek bir hız vermek için yeterli güce sahip olmadığını belirtmektedir.

1908 yılında II. Meşrutiyetin ilanı, kadınların yaşama katılım, çalışma hayatına girme ve yüksek öğrenim görme gibi isteklerini de duyurmalarını beraberinde getirmiştir. Anlatım özgürlüğünün sağlanması kadınlara ilişkin sorunların tartışılmasına olanak sağlamıştır (Arat 1986: 107). Bu dönemde, kadın hakları mücadelesi de ivme kazanmıştır. Dönemin üzerinde durulması gereken en önemli özelliği, kadınların dernekler aracıllğıyla kendi hak mücadelelerinde etkin olmalarıdır (Nizam 1993: 23). Başka bir ifadeyle, bu dönem tam da kadın hareketinin kurumsallaşmaya başladığı zamanlardır.

Kırmızı-Beyaz Kadın Derneği ve Teali-i Nisvan kurulan ilk derneklerdendir. Bu derneklerin yanı sıra 1909-1918 yılları arasında kadınların sorunlanını araştıran, incelemeler sonucunda tartışma ortamı hazırlayarak çözümler öneren pek çok gazete ve dergi yayınlanmaya başlanmıştır. Kadın, Kadınlar Dünyası, Kadınlık, Osmanlı Kadınlar Alemi, Kadın Kalbi adı altında çıkan dergilerde kadın sorunu yoğun bir biçimde tartısılmaktadır (Arat 1986: 108).

Görüldüğü gibi kadın hareketinin II. Meşrutiyette güçlenmesinin en önemli nedenlerinden biri, farklı bir örgütlenme tarzının denenmesi ve değişik amaçlı da olsa pek çok kadın derneğinin kurularak kadınların bu derneklerde bir araya gelmeleridir. Bu dönemde kadın hareketinin dergiler aracilığıla sürdürdüğü mektuplaşmalarla özel bir iletişim ağının kurulduğu ve bu mektuplaşmaların da kadın dayanışmasını hem Osmanlı içinde hem de uluslararası düzeyde sağlamaya yönelik olduğu görülmektedir. Bu amaçla Avrupa'daki özellikle de İngiltere ve Fransa'daki kadın hareketleri izlenmiş ve bu ülkelerdeki kadın dernek ve kuruluşlarıyla yazışmalar yapılmıştır (Nizam 1993: 25). Türkiye'de feminizm kavramı ilk kez II. Meşrutiyet döneminde duyulmuş, aydın kadınlar yayınlar yapmıss dernekler kurmuştur. Bu kıpırtılar bu günkü anlamda feminizm değilse bile kadınlar seslerini duyurmaya başlamışlardır. Ancak bu sesler İttihat ve Terakki ile ardından da savaşların patlamasıyla kaybolmuştur (Tekeli 1988: 329).

Yukardan belirtilen örneklerden anlaşılacağı gibi bu dönemin kadınlar açısından en önemli özelliği kadınların hak savaşımında doğrudan etkili olmalarıdır. Bunun temel nedeninin 1912 Balkan Savaşı ve I. Dünya Savaşı’nın etkileri olduğu ileri sürülmektedir. Balkan Savaşı kent soylu kadınları sosyal hizmet amacıyla derneklere yöneltmiş I. Dünya Savaşı ise kadınları çalışma yaşamına sürüklemiştir (Tekeli 1982: 198-199). I. Dünya Savaşı, savaşa katılan tüm toplumlarda olduğu gibi Osmanlı toplumunda da savaşan erkeklerden boşalan iş yerlerine kadınların alınmasına yol açmıştır. 1915’te kadınlar için farklı bir dönem noktasıdır demek yanlış olmaz. İlk defa kadınların erkeklerden boşalan işlerde çalışarak kamusal hayata katılmaları aslında bir bakıma geri döndürülemez bir hak talebi sürecini de beraberinde getirmiştir. Çünkü bu süreçte, I. Dünya Savaşı'na katılan erkeklerden boşalan yerlere mesela postanelerde ve çeşitli memuriyet alanlarında, askere giden erkeklerin yerini orta sınıf kadınlar almıştır. Kadınlar bu süreçten sonra giderek hemşirelik ve ortaokul öğretmenliği de yapmaya başladılar. İş yaşamında yerini alan kadınların yanı sıra, birçokları da evlerinden çıkarak sosyal yardım işleriyle uğraştılar. Bu gelişmelerin toplumsal yaşamın tümünde değişimlere yol açmaması düşünülemezdi. Nitekim, kadınlar ile erkekler arasındaki katı sınırlar artık aşınmaya başlamıştı (Abadan Unat 1979). Bu dönemde 
aydınlar arasında kadın sorunu tartışmaları giderek daha ciddi boyutlar kazanmaya başlamıştı. Gerek İslamcı kesimin kadının erkekten aşağı olması gerektiğini savunan görüşleri, gerekse kadının sosyal ve siyasal haklarını elde etmesi gerektiğini savunan kesimin görüşleri arasındaki tartışmalar şiddetlenmiş ancak gerek kadın dernekleri gerekse yayın organları kadın hakları mücadelesini kadınların eğitim ve eğlence yerlerine gidebilme hakkı ile sınırlamışlardır (Nizam 1993: 26).

1917'de kabul edilen Hukuk-u Aile Kararnamesi aynı zamanda İslam'n ilk yazilı aile hukuku olma niteliğini de taşımaktadır. Bu kanun, kadınlara boşanma hakkı tanıyarak evlenmeyi din adamının yetkisinden devlete devrederek ve çok karılılığı kadının rızasına bırakarak şeriattan tamamıyla kopmasa bile ilerici özellikler taşımaktadır. Kuşkusuz kadınların bu hakların elde edilişinde yeterli mücadeleleri olmamakla birlikte özellikle savaş nedeniyle toplumsal yaşama ve çalışma hayatına katılmaları ile elde ettikleri birtakım hakların etkisi büyüktür. Daha sonra buna benzer bir baskı ortamı yaratacak toplumsal olay ise Kurtuluş Savaşı olacaktır (Nizam 1993: 27).

I. Dünya Savaşı öncesinde kadın erkek eşitliği çerçevesinde sürdürülen kadın hakları, Osmanlı'nın savaştan yenik çıkması ve topraklarının işgali üzerine bu kez milliyetçilik boyutunu kazanmıştır (Nizam 1993: 27). Kurtuluş Savaşı her kesimden kadını etkilemiştir. Köylü kadın sırtında cephane taşıyarak bu savaşa destek vermiş, kentlerde fabrikalarda kadınlar üretimi üstlenmiş, güdülen bağımsızlık siyasetine destek vermek için örgütlenmişlerdir (Süllü 1988: 72). İşgal kuvvetlerinin yurdu işgal etmesine tepki olarak düzenlenen mitinglerde kadinlar hem meydanları doldurmuş hem de Halide Edip Adıvar, Muallimler Derneği Başkanı Nakiye Elgün, öğrenci temsilcisi Münevver Sami gibi kadınlar kürsülere çıkıp halkı düşmana başkaldırmaya çağırmışlardır. Pek çok kadın da Mustafa Kemal'in Anadolu'da oluşturduğu Kuvayi Milliye’ye katılmışlardır (Abadan Unat 1979: 19).

Kurtuluş Savaşı kadınların kendi hakları için mücadele verdikleri bir dönem olmamıştır. Verdikleri mücadele erkeğin yanında yer alarak ülkenin düşmandan kurtulup bağımsızlı̆̆ına kavuşabilmesi içindir. Fakat bu da kadınlar açısından artık sadece kendi sorunlarını değil, toplumsal sorunları tartışabilecek bir düzeye geldiklerinin göstergesi olması nedeniyle önemlidir (Süllü 1988: 72). Kurtuluş Savaşı Türk kadınının hakları için bir dönüm noktası olarak kabul edilebilir. Kadınların milli mücadeledeki çabaları, henüz yasalar önünde hak sahibi olmayan Türk kadınlarının Yurttaşlık Yasası ile birlikte ulusal yapı içinde yerini alması ve özellikle başta öğrenim olmak üzere kendisine sağlanan olanaklardan yararlanmaya başlaması sonucunu doğurmuştur (Arat 1986: 117). Son kertede vurgulanmalıdır ki, Türkiye'de kadın hakları özelinde bu gelişmelerin Avrupa'dan yıllarca geride kaldığı eleştirilerinin haklılık payı olsa da ülkenin içinde bulunduğu konjonktür değerlendirildiğinde kadın hareketinin gelişim sürecinin kendi dinamikleri olduğu gerçeği göz ardı edilmemelidir.

\section{Cumhuriyet Döneminde Kadınların Konumu}

Bağımsızlı Savaşından sonra Kemalist milliyetçi kadroların önderliğinde Türkiye Cumhuriyeti kuruldu. Bu savaş kadınların erkeklerin görevlerini başarılla üstlenebildiklerini kanıtlamış olsa bile kadınların geleneksel rollerinde köklü bir değişiklik yaratmadı. Zaten Berktay (1994: 26) belirttiği gibi, "Türk kültürü, erkek egemenliğini meşrulaştıran ataerkil değerleri yücelten ve kadınları 'kendi yerlerinde' tutan cinsel iş bölümünü sorgulamasız benimseyen bir kültürdür ve kolayca tahmin edilebileceği gibi 'kadınların yeri', kadınların kendileri tarafından benimsenmiş değildir”. Bu bağlamda, ülkeleri için savaşan ve kendi geçimlerini sağlayan kadınlar yeni edindikleri hak ve rollerin genişletilmesi şöyle dursun bunların meşruluğunu bile pek savunmuyorlardı. Böylece 1920'lerin sonları ve 1930'ların başlarında kadınlara toplumsal ve siyasal hakların hangi koşullarda sağlanacağını belirleyenler Cumhuriyet Türkiye'sinin kurucuları ve önderleri olan erkekler oldu (Arat 1986). Yapilan reformlar somut ilerlemeleri mümkün kilan çerçeveleri sağladı. Kadınların statüsünde meydana gelen iyileşmeler Kemalistlerin mücadele ettikleri geleneksel değerlerin değişmesi için bir araç olduğu kadar kendi başına bir amaçtı (Abadan Unat 1979). Cumhuriyet'in "kadın evrimi”" olan yasal düzenlemelerin başlıcaları 1924 
y1lında çıkan Tevhid-i Tedrisat Kanunu, 1925 yllında çıkan Kiyafet Kanunu ve 1926'da kabul edilen Medeni Kanun'dur. Medeni kanun kadınlara evlilik, boşanma, veraset konularında eşit haklar getiriyordu. Ancak kadının asli görevinin ev işi olması, aile reisinin erkek olması, kadının çalışmasının kocasının iznine tabi oluşu gibi düzenlemelerle bir ölçüde gelenekselliğini de koruyordu (Nizam 1993: 29).

Kadınların siyasal yaşama katılmaları ve siyasal haklarını kazanmaları ise gecikmeyle gerçekleşmiştir. Illk olarak 1930 'da belediye seçimlerinde seçme ve seçilme haklarını kullanmışlar, 1934'de genel seçimlere katılabilmişlerdir. Diğer ülkelerde olduğu gibi kadınlar bu haklarını elde edebilmek için bir savaș vermemișler bu haklar kendilerine verilmiștir. Bu hakların verilmesinin de kadınları düşünmekten çok modernleşme amacıyla yapıldığ1 düşünülmektedir (Tekeli 1988: 7475). Bir başka deyişle, kadınlar için olan bütün gelişmelerin bir bakıma da Batı ile uyumlu olma ve bütün dünyaya ne kadar modern olduğumuzu göstermek için kullanıldığını söylemek yanlış olmayacaktır.

Ne amaçla olursa olsun bu hakların verilmesi pratikte kadınların oldukça işine yaramış ve hemen ardından ilk genel seçimlerde meclise 18 kadın girmiştir. Bu sayının Batılı kadınların o dönemlerde meclisdeki sayılarından daha fazla olduğu görülmektedir (Tekeli 1988: 77). Sözü edilen reformların getirdiği hukuksal eşitlik birçok Batı demokrasisinde kadınlara benzer bir statünün o dönemde henüz sağlanmamış olduğu dikkate alınırsa oldukça ileri bir aşamadır. Ancak Batı'daki durumun aksine bu hakların bir kadın hareketinin sert mücadeleleri olmaksızın kazanılmış olması bunların ne gibi stratejik amaçlarla verilmiş olabileceği konusunda tartışmalara yol açmıştır. Kemalist feministler diyebileceğimiz ilk kuşak Cumhuriyetçi kadın yazarlar demokratik bir toplumun inşası açısından bu reformların kaçınılmazlı̆̆ını vurgulamaktadır. Bu yazarlar ayrıca Atatürk'ün kadın hakları konusuna kendi başına bir amaç olarak ilgi duyduğunu da belirtmişlerdir.

Alternatif bir görüşü ise Şirin Tekeli dile getirmekte ve kadınlara ilişkin reformların kendi başlarına birer amaç olmaktan çok belli bir amaç için, yani modernleşme amacıyla, araç olduklarını savunmaktadır. Tekeli'ye (akt. Abadan Unat 1979) göre reformların esas amacı, kadınların aktif politikaya katılmalarını sağlamak değil kadınların parlementoya girişini bir simge olarak kullanma isteğidir. Peçe, örtünme, kadınların tecridi ve erkeğin çok eşliliği gibi uygulamalar yüzünden din tarafından en görünür biçimde ezilen grup olarak kadınların özgürleştirilmesi Atatürk’ün teokratik devlete yönelttiği saldırı açısından merkezi bir önem taşıyordu. Kadınlara oy hakkının tanınması, Atatürk'ün kendi tek parti rejimini zamanın faşist diktatörlüklerinden ayırt etmek için başvurduğu bir şeydi. Faşist devletlerin "Çocuk, Kilise, Mutfak" ideolojisinin yerine Türkiye, bu sayede, kadınları parlementoya girebilen bir ülke görünümü sunarak simgesel olarak diğer Batılı demokratik ülkeler arasında yer aldığını göstermek istiyordu (akt. Abadan Unat 1979). Kemalist Cumhuriyet son çözümlemede ataerkil bir devlettir; ancak Cumhuriyet'in kadınlara ilişkin uygulaması ile şeriatın egemen olduğu Osmanlı Devleti'nin uygulaması arasında kadınlar açısından çok önemli farklar olduğunu ve ayrıca kadınların Kemalist dönemde elde ettikleri haklar uğruna çok önceden mücadeleye başlamış olduklarını unutmamak gerekir (Abadan Unat 1979).

Kemalist Reformlar bir yandan özel alanın katı sınırlarını gevşettiği kapılarını kamusal alana açarak kadınların olanaklarını genişletti ve statülerini yükseltti. Ancak kadınların kamusal alana girişlerinin önemli ölçüde erkek reformcuların denetimi altında gerçekleşmiş olması kadınların özerk siyasal insiyatiflerinin bastırılmasına yol açtı. Örneğin, Haziran 1923'te kurulmasına girişilen Kadınlar Halk Fırkasına izin verilmedi. Hem kadınların siyasal haklarının olmaması hem de böyle bir girişimin bölücülük olacağı gerekçesiyle kadınlara parti yerine dernek kurmaları önerildi. Bunun üzerine 1924'te Türk Kadınlar Birliği kuruldu. Bu birlik, 1935’te kapandı. Birliğin başkanı Latife Bekir kamuoyuna sunduğu açıklamada Türk kadınlarının artık tam eşitliğe ve anayasal güvencelere kavuştuklarını dolayısıyla birliğin amaçlanına tümüyle ulaşıldığı için varlığını sürdürmesine gerek olmadığını ileri sürüyordu. Cumhuriyet rejimi devlet desteğindeki feminizme bir alan açıyor ama aynı zamanda onun parametrelerini tanımlayıp sınırliyordu (Abadan Unat 1979). 
Cumhuriyet döneminde Kemalizm’in batıllaşma ideolojisi çerçevesinde Medeni Kanun'daki düzenlemeler ve oy hakkı gibi yasal düzenlemeler ile devlet kendi eliyle bir devlet feminizmi oluşturmuştu. Bunun yanı sıra kadınlara eğitimden olanak tanıyarak öğretmenlik gibi alnalarda kadınların meslek sahibi olmalarına önem verildi. Ancak bütün bu gelişmelerle birlikte laik devlet kadınlara tanıdığı bu hakların yanında 1935'te Türk Kadınlar Birliğini kapatarak bağımsız kadın hareketinin bir parçasına son verilmiş oldu (Nizam 1993: 29). Cumhuriyet Döneminde 1950'lerden 1970'lerin ortalarına kadar uzanan zaman dilimi içinde kurulan kadın derneklerine baktığımızda laik düzenin ve Atatürk'ün İslami düzenin kaldırılması ile kadınlara sağladığı olanakların korunmasının başlıca amaç olduğu görülmektedir. Bu süreçte kadın örgütlerinin hepsi Kemalist devrimin kadınlara sunduğu olanaklar için minnettarlıklarını dile getirmişler ve her firsatta Türk kadınının diğer Batı ülkelerine kıyasla hukuken çok daha ileri bir durumda olduklarını vurgulamışlardır. Kadın sorunu olarak gündemi oluşturan ise kırsal kesimdeki eğitim olanaklarından yararlanamayan kadınların durumudur (Nizam 1993: 32). Bu bağlamda kadın sorunu olarak görülen mesele aslında sadece buz dağının görünen kısmından ibarettir.

Buz dağının altta kalan kısımlarında ise bambaşka kadın meseleleri vardır. Mesela, çok partili döneme geçtikten sonra kadınların parlamenter gücü olumsuz olarak etkilenmiştir. Kadın adayların seçilme şansı ortadan kalkmış siyasal partilerin daha çok sandalye elde etmek için giriştikleri rekabet ortamı kadınların zararına olmuştur. Dolayısıyla parlementodaki kadın milletvekili sayısında azalma görülmüştür (Arat 1986: 128). Çağdaşlaşma, endüstrileşme ve gelişme olguları kentleşmeyi hızlandırıcı rol oynamıştır. Büyüyen kentlerde açılan yeni iş alanları her gün daha fazla sayıda kadının çalışma yaşamına katılmasını beraberinde getirmiştir. Ayrıca ekonomik güçlükler nedeniyle kadınların aile bütçesine yardım etmek için çalışması, onlara ev işlerini kocasıyla paylaşmak gibi bir hakkı beraberinde getirmemektedir. Çalışan kadın geleneksel ailenin düzenine de aynı zamanda uymak durumunda kalmaktadır. Evlilik Türkiye'de hangi eğitim düzeyine sahip olursa olsun kadının toplumsal rolünü gerektiği gibi yerine getirebileceğine inanılan asıl kurumdur (Tekeli 1988: 320-322). Bu bağlamda kadınların aslında çalışma yaşamına katılmaları kendi ev içi statülerinde bir değişikliği beraberinde getirmemiş, tam tersine kadınlar Marksist feminizmin iddia ettiği gibi iki patrona birden hizmet etmeye başlamıştır; ev içinde kocalarına, iş yaşamında ise patronlarına.

Kentsel kesimde kadının eğitim düzeyinin yükselmesi çalışma yaşamına artan oranda katılması sevindirici bir gelişme olarak nitelendirilmesine karşın pek çok sorunu da beraberinde getirmektedir. Kadın yetiştirildiği kültürel değerlerle çalışma yaşamının yanı sıra ev işlerini de tamamen yüklenmek zorundadır. Erkeklerin geleneksel yetiştirilmeden gelen istek ve tutumları kadınların bu yükünü hafifletmelerini engelleyici bir rol oynamaktadır. Çalışan kadınların en büyük problemlerinden biri de çalışmaya gittiklerinde çocuklarının bakımıdır (Süllü 1988: 77).

1970'lerin sonunda yeniden gündeme gelecek olan kadın sorunu bu kez 70'lerin Türkiye'sine damgasını vuracak sosyalist gençlik hareketi ile anlam kazanmıştır. Ancak bu dönemim kadın hareketi anti-feminist bir nitelik taşıyor ve Marksizmin kadın konusundaki tahlillerine dayanıyordu. Kadının kurtuluşunun ise ancak sosyalist bir düzen içinde mümkün olabileceği ve kadınların sınıf mücadelelerinde erkeklerle birlikte hareket etmesi gerektiği görüşü hakimdi. Kadının ezilmişliği ise özellikle emekçi kadın üzerinde ifadesini bulacaktı. Çünkü işçi kadınlar hem kapitalist sistem içinde emeğiyle hem de ataerkil düzende ev içindeki emeğiyle iki kez sömürüye maruz kalıyordu. 1970’lerin radikal sol örgütlerinin hepsi kadınların tek kurtuluş yolunun sosyalizmin kurulmasına bağlı olduğunu onun için kadınların sosyalizm mücadelesinde yer almaktan başka çaresinin olmadığını vurguluyorlardı (Nizam 1993: 33).

Cumhuriyet'in ilanından sonra kadına tanınan haklar, kadınlara daha fazla söyleyecek söz bırakmamıştır. Devlet eliyle gerçekleştirilen feminizm sayesinde, kadınların kendi çabalarıyla hak talep etmesine gerek kalmamıştır. Daha önceki dönemin feministleri bu dönemin Kemalistleri arasında yer almış ve Kemalizm bu dönem feministleri için feminizmin esas anlamıyla eşdeğer olmuştur. Bu dönemde Kemalist kadınların dışında kalan kadınlar ise İslami değerlere göre bir 
yaşam biçimini benimsemişlerdir. İslami değerler ve onun önerdiği yaşam biçimi, kadının yerinin ev, görevinin ev işi ve analık olduğunu kabullenmesini sağlayıcı rol oynamaktadır. Türkiye'de var olan azgelişmiş ekonomik yapının getirdiği kadının aile kurumuna bağlılığı ve ailenin kadın için tek seçenek oluşu feminizm için bir diğer engeli oluşturmaktadır. Türkiye'deki eğitim sisteminin kadınlar için gereken bilinç düzeyine eriştirebilir düzeyde olmayışı kadınlara ses çıkartacak cesareti sağlayamamaktadır. Ayrıca pek çok ülkede feminist harekete destek veren sol ideoloji de Türkiye'de kadına "ana, fedakâr kadın" diye seslenmektedir. Böylelikle Türkiye'de var olan toplumsal yapı, kadının ezildiği bilincine varabilmesi ve bunu aşmak için cesaret bulabilmesi yine aynı yap1 ve ideolojilerce engellenmiştir (Tekeli 1988: 322-333). Böylelikle gerçek bir feminist etkinlik oluşması 1980’lere dek gecikmiştir.

\section{0'ler ve 1990’larda Kadınların Konumu}

Türkiye'de kadın hareketi, olayların eylemlerin ve taleplerin yoğunluğu bakımından iki ayrı döneme ayrılmaktadır. 1910-1920 arasındaki ilk dönemle, 1980’lerden günümüze kadar olan ikinci dönem. Bunlardan ilkinden önce 40-45 y1l süren bir hazırllk dönemi, diğerinden önce de Tekeli’nin (1998: 337-338) “çorak yıllar” adını verdiği bir duraklama dönemi vardır. Bu dönemlere Türkiye'deki feminist kadın hareketinin birinci ve ikinci dalgaları demek mümkündür.

$\mathrm{Bu}$ dönemselleştirme ile Batılı feminist hareketin kaba dönemleştirmesi arasında paralellikler vardır. Batı'da da I. Dünya Savaşı öncesi birinci dalga feminist hareketten söz edilir. II. Dünya savaşı arası dönemde faşizmin, otoriter rejimlerin kurulduğu toplumlarda feminist hareketin bastırılması söndürülmesi söz konusudur. Demokratik toplumlarda ise dalganın geri çekildiği görülür. Bunda doğrudan bir baskı olmaksızın kadın hareketinin oy hakkı gibi taleplerini gerçekleştirdiği ve amaçlarına ulaştığı sanrısıyla geri çekilmesi etkili olmuştur. Türkiye'de feminist hareketin Batı hareketleriyle paralelliği 5-10 yll gecikmeyle de olsa söz konusudur. Ancak, Türkiye'de kadınlar bir yandan Alman Faşizmi kadar acımasız olmasa da tek partili otoriter rejimin baskısı bir yandan da demokratik batılı toplumlarda karşımıza çıkan medeni ve siyasi hakların kazanılmasıyla davanın kazanıldığı yani amacına ulaşma sanrısı sonucu geri adım atmışlardır (Tekeli 1998: 338).

1980'lerle birlikte özellikle kadın hareketi kamusal ve özel alan arasındaki belirgin ayrımlaşmanın sorgulanmasını bir politik mücadele eksenine oturtmakla işe başlamıştır. "Özel olan politiktir" sloganının özetlediği bu başlangıç, tıpkı ikinci kuşak batılı kadınların gündemini içeriyordu fakat tek bir farkla, dönemler farklıydı. 1960’larda Batılı kadınların kullandığı bu slogan Türkiye'ye 1980'lerde taşınabildi. İkinci kuşak kadın hareketi olarak tanımlanan 1980-1990 arası Türkiye'de kadınların toplumsal cinsiyete ilişkin varoluş problemlerinin tartışıldığı kadın olmanın ve kadınlığın anlamlarının belirginleştiği feminizmin bir toplumsal proje olarak tartısıldığı bir dönem olmuştur. Bu dönemi anlatan en uygun kavramlar ise "bilinç yükseltme", "güçlenme" ve "duyarlılık yaratma" olarak tarif edilebilir (Timisi ve Ağduk Gevrek 2002: 14-15).

70'li yılların politik ortamında kadın sorunu Marksizmin sınıf tahlillerine dayanarak antifeminist bir öz taşıyordu. 12 Eylül 1980'le birlikte sol mücadelenin fiilen sona erdirilmesi ve mücadelenin sağ-sol ekseninden uzak tutulmaya çalışılması, özellikle siyasal partilerden ve ideolojilerden uzak kalmaya çalışan kadın hareketinin gelişmesi için de olanak tanıyordu. İşte bu kez 70'li yıllardakinin aksine kadınların kadın oldukları için yaşadıkları sorunları ön plana çıkaran feminist ideoloji Kemalizm'in kadın konusuna sağladığı saygınlıktan da yararlanarak 80'li yıllarda kadın hareketine yol gösterici olarak damgasını vuracaktır. 1982'de İstanbul'da Gazeteciler Cemiyeti'nde YAZKO'nun düzenlediği sempozyumda feminizm Türkiye'de ilk kez kamuoyu önünde açıkça savunuldu (Nizam 1993: 34). 1983'te YAZKO'nun yayınladığ1 Somut dergisindeki sayfa, 6 aylık kısa yayın hayatı ile hem İstanbul'da hem Ankara'da feminist kadınların en çok takip ettiği yayın haline geldi. Birçok tartışma bu sayfadaki tartışma noktalarından filizlendi. $\mathrm{Bu}$ tartışmalar daha yakından tanıyan az sayıda kadının evlerinde toplanarak gerçekleştirdiği bir biçimde sürüyordu (Timisi ve Ağduk Gevrek 2002: 15). 
Kadınların toplu eyleme geçişi ise ilk kez Birleşmiş Milletlerin "kadın on yllı" sonunda 1985’te imza koyduğu “Kadınlara Karşı Her Türlü Ayrımcılığın Önlenmesi Sözleşmesinin” (CEDAW) uygulamaya konulması için dilekçe kampanyasının açılması ile başlamıştır. Toplu eylemlere başlanılması ile birlikte kadın hareketi de farklı bakış açılarıyla buluşmaya başlamıştır ve çeşitli kadın grupları oluşmuştur. Örneğin, Feminist Dergisi ve Kaktüs Dergisi çıkmaya başlamıştır. 1987 Mayıs'ında yürüyüşle açılan "Dayağa Karşı Dayanışma” kampanyasının hazırlık sürecinde örgütlenmenin gerekli olduğuna inanan bir grup kadın 25 Haziran 1987'de AKKD'1 Ayrımcıllğa Karşı Kadın Derneği) kurdular (Nizam 1993: 35).

Ankara'da da çalışmaların yaygınlık kazanması amacıyla Kadın Dayanışma Derneği Ocak 1989'da kuruldu. Yine Perşembe Grubu, feminizm ve kadın hareketi konusunda Ankara'da çalışmalarını sürdürüyordu. Şubat 1989'da Ankara ve İstanbul'daki kadınların bir araya gelmesiyle 1. Feminist Haftasonunda öneriler ve alınan kararlar ile 1989 Kasım'ında "Cinsel Tacize Hayır" kampanyası başlatıldı. Kampanyada kadınlara kendilerini saldırılara karşı korumaları için mor iğneler satıldı (Nizam 1993: 36).

Feminist kadınlar, kadınlık durumuna ilişkin sorgulamalarında kadın ezilmişliğinin ataerkil düzenden kaynaklandığını saptamışlar ve ataerkil düzenin uzantısı olan devlete ve kurumlarına bu çerçevede karşı çıkmışlardır. Ancak Türkiye'de feminist hareketin kökleri Kemalist devletin reformlarına dayanır. 80’lerde gelişen İslamcı akım ve kadın grupları karşısında feminizm Kemalist devletin laiklik ilkesini savunur. İște feminist hareketin yaygınlık kazanması ve öne çıkmasındaki en önemli etken de 1980 sonrasının liberal ekonomi ve politikaya geçilmesi ile öne çıkan bireyselliğin feminist ideolojide karşılığını bulmasıdır. Özellikle Feminist Dergisi’nin yazılarında dikkati çeken kadınları birey olarak güçlü kılmaya ve saygınlık kazandırmaya yönelik bireyselliği savunan yazılar kadın hareketinin gündeme getirdiği en önemli tema olmuştur (Nizam 1993: 36).

Feminist hareketin siyasal bask1 ortamında politika yapabilmesi önemsenmemenin ve Kemalist geleneğin kadın konusunda meşruiyet tanımasından öte, feminizmin liberalizme olan katkısıdır. Gerçekte de feminist hareket teoride devlet ve kurumlarına karşı olmakla birlikte hiçbir zaman düzene karşı olmamış hatta liberal laik ve demokratik bir toplumu kadın kuruluşu için bir önkoşul olarak görmüştür (Nizam 1993: 37). Kadınların kadın olmaktan kaynaklanan sorunlarına çözüm arayan feminist kadın hareketi dışında kendilerini sosyalist feminist olarak tanımlayan kadınlar ve sosyalist kadınlar da kadın hareketinin içinde yer aldılar. Kaktüs çevresinden kadınlar kadınların kurtuluşu için tek başına feminizmin yeterli olmadığını çünkü feminizmin bütünsel bir toplum projesine sahip olmadığı gerekçesiyle kadın kurtuluşunun maddi koşullarını sağlayabilecek bir sistem olarak sosyalizmi görmektedirler. Her türlü ezilme ve sömürüye karşı çıkan bir ideoloji ve toplumsal proje olarak cinsler arası eşitsizliğin de yok edilmesini gündeme getiren sosyalizmin feminizm olmadan tam olarak gerçekleşemeyeceğini savunmaktaydılar. Ancak bu kadınlar pratik süreçte feminist kadınlarla birlikte davranmışlar ve eşitlikçi feminist akıma yakın olmuşlardır (Nizam 1993: 38).

1990’ların başına gelindiğinde 80’lerde açılan kadın derneklerinden bir bölümü kapanmış örgütleşemeyen gruplar dağılmıştır. Başlangıçtaki coşku ve heyecanın aynı düzeyde sürmesinin beklenilemeyeceği zaten aşikardır. Buna karşın, bu on yıllık kadın hareketinde bir kurumsallaşmaya doğru yönelim gözükmektedir (Kılıç 1998: 357). 1993 yılında Ankara'da Kadın Dayanışma Vakfı kuruldu. Feministlerin başvuruları ile Şişli ve Bakırköy Belediyelerince kadın sığınakları açıldı ve feministlerin kendileri de 1990 Haziran'ında “Mor Çatı Kadın Sığınma Vakfını" kurdular. Yine kadın araştırmaları yapmak ve bu araştırmaları toplamak amacıyla bir grup feminist kadının çabasıyla "Kadın Eserleri Kütüphanesi ve Bilgi Merkezi” kuruldu. İstanbul Üniversitesinde "Kadın Sorunları Araştırma ve Uygulama Merkezinin" 1990'da kurulmasıyla da Türkiye'de ilk kez kadın araştırmaları üniversite bünyesinde bağımsız bir birim olarak yer almışır (Nizam 1993: 36). 
1995 yllında yayına başlayan Pazartesi ile bağımsız bir feminist dergi için kolay olmayan bir başarı göstermiş ve aylık yayınını sürdürebilmiştir. Yine 1990’larda gözlenen bir eğilim İstanbul, Ankara, İzmir, Gaziantep gibi merkezlerde farklı görüşlerdeki grupların belli konularda iş birliğini sağlamak amacıyla oluşturulan kadın platformlarıdır (Kılıç 1998: 358).

90’larda feminist hareketin, 80’lerdeki feminist hareketten temellendiği göz ardı edilemez. Özellikle feminist terminolojinin birçok kadın örgütü tarafindan kullanılıyor olması medyanın, devlet kurumlarının ve günlük konuşma diline girmiş olması 80’lerde gerçekleştirilen eylemlerin ve kampanyaların sonucunda olmuştur. 80’lerde daha gevşek örgütlenmeler içinde ve daha çok bilinç yükseltme grupları şeklinde yapılan toplantılarda ortaya çıan politika önerileri 90’larda kamu politikaları haline getirilmeye çalısıllmaktadır. Kurumsallaşma ve kamu politikalarının içine sızma/girme (gender mainstreaming) 1980'lerde başlayan bir sürecin 1990'larda kendini gösterdiği önemli bir kazanımlardır (Timisi ve Ağduk Gevrek 2002: 38). 1980’ler bir taraftan feminist literatürün Türkçe’ye kazandırıldığı yıllar olmuştur. Bu eserler 1990'lı yıllarda gelişen ve bugün üçüncü kuşak feministler olarak adlandırdığımız akademik feminizmin gelişmesine yol açmıştır. 90’lardan itibaren akademinin içinde ciddi bir feminist literatür oluşmaya başlamıştır (Timisi ve Ağduk Gevrek 2002: 38).

\section{0'li Yıllarda Türkiye'de Kadın Hareketi}

Türkiye'de kadın hareketi özelinde 2000'li yıllardaki gelişmelere baktı̆̆ımız zaman, cinsiyet eşitliği politikalarının önceki ylllara göre bir gerileme dönemine girdiği görülmektedir. Bu dönemde Hükümetteki çalışmaların da etkisiyle toplumsal cinsiyet eşitliği tartışmalarının yerini kadının aile içindeki konumunun aldığ1 görülmektedir. Kurumsallaşmanın en önemli duraklarından biri olan Kadının Statüsü Genel Müdürlügü’nün $(\mathrm{KSGM})^{3}$ de toplumsal cinsiyet eşitliği çalışmalarında gerilemeler olduğu görülmektedir. Türkiye'de kadınlara verilen hakların genellikle modernleşme çabası altında olduğu görülmektedir. Günümüzde de "kadın eğitimi, sağlık koşulları, istihdama katılımın desteklenmesi gibi amaçlar sürdürülecektir; bunlar toplumsal ve ekonomik gelişme açısından önemlidir. Ancak bu gelişmelerin, cinsiyet eşitliği amacından uzak kalacakları gibi, liberal ekonomi politikalarının da gölgesinde kalacaklarını söylemek abartı olmayacaktır” (Koray 2011: 42).

Koray (2011), Kandiyoti (2011) ve Sancar (2011) gibi kadın çalışmalarının önde gelen isimlerinin belirttiği üzere, Adalet ve Kalkınma Partisi'nin (AKP) iktidar olduğu 2002 yllından itibaren, Türkiye'de kadın hareketi için yeni bir dönem başlamıştır. Sancar'a (2011: 84) göre, "ideolojisi gereği cinsler arasında bir eşitlik olduğunu kabul etmeyen bir siyasi hareketin mirasçısı olarak, kadın erkek eşitliğini doğrudan kabul etmeden, kadının insan hakları yaklaşımını bir ölçüye kadar benimsedi; bazı noktalarını kendi ideolojisine göre dönüştürerek ele aldı".

Sancar (2011: 76), 2000'lerden sonra Türkiye'de kadın hareketinin 2000'den 2005'e kadarki dönemini "Devlet içinde kurumsallaşma, kadın örgütleri arasında ittifaklar" ve 2005'ten sonraki dönemi ise "Proje feminizmi dönemi (apolitik politikleşme) ve liberal demokrasinin kadın hakları konsolidasyonu" olarak tanımlar. Örneğin 2000'lerin başında kadın hareketinin aktörleri Türkiye'de büyük uğraşlar ve lobicilik faaliyetlerinin ardından, Avrupa Birliği’ne adaylık süreci rüzgarını da arkalarına alarak iki önemli gelişmeye imza atmışlardır. Bunlardan ilki, 2001 yılının Kasım ayında kabul edilen yeni Medeni Kanun'da "erkek ailenin reisidir" ifadesi kalkmıştır. Bununla beraber, yaşanılan mesken, evlilik birliği içinde edinilen mallar, boşanma, çocukların velayeti, miras ve çalışma ve seyahat hakkı gibi konularda tam eşitlik sağlanmıştır (Kandiyoti 2011: 55). Bununla beraber, 2004 yllındaki Türk Ceza Kanunu’ndaki değişiklikte gelenekler sebebiyle adam öldürmedeki (namus cinayeti) ceza indirimi kalktı, evlilik içi tecavüz suç sayıldı, tecavüz ettiği kadınla evlenen erkeğin cezasında indirim ya da erteleme yoluna gidilmesine son verildi, iş

\footnotetext{
${ }^{3}$ KSGM'nin yapısı yıllar içinde çok fazla değişiklik göstermiştir. Daha detaylı bilgi için Kuloğlu, C. (2017). Never Ending Nightmare: Violence against Women in Turkey. International Journal of Multidisciplinary Thought. 06(01): 213-220.
} 
yerinde taciz suç olarak tanımlandı. Bakire/bakire olmayan ve evli/bekar kadın şeklindeki ayrımlar ortadan kaldırıldı (Kandiyoti 2011: 56).

Türkiye'de bugün kadın hareketinde daha ziyade şiddet, siyasal katılım ve kadın girişimciliğine odaklanılmış durumdadır (Koray 2011: 45). Bu bağlamda kadın örgütleri kolektif bir çalışmadan ziyade kendi başlarına uluslararası kuruluşların açtıkları kadın fonlu proje çağrılarına yönelmektedir. Artık kadın örgütleri kadın sorunlarının çözümünü toplumdan ya da devletten beklemiyorlar. Sancar'ın (2011: 101) "proje feminizmi” olarak adlandırdığı bu yapısal durum, kadın hareketinin sadece Türkiye'de değil tüm dünyada örgütsel, ideolojik ve politik dönüşümüne sebep olan bir etkendir. Sancar'a göre (2011: 102), “proje feminizminin kadın örgütlerinin yapısını dönüștürdüğü gerçeği karşısında geriye kalana hala kadın hareketi denip denemeyeceği tartışılmaya muhtaç bir konu. Çünkü bu dönüşüm kadın örgütlerini siyasetten, siyaseti de kadın örgütlerinden ve özellikle de feministlerden uzak tutuyor”. Bu bağlamda geriye kalan, dağınık, apolitik ve detaylara gömülmüş bir halde eleştirel bakıştan uzak bir kadın hareketidir.

\section{Sonuç ve Tartışma}

Günümüzde Türkiye'de kadın hareketinin duraklama ve hatta gerileme dönemine girmiş bulunduğu inkâr edilemez bir gerçektir. Onca yıllık bir mirasa sahip olmasına rağmen, kadınların bugün Türkiye'de geldikleri nokta neredeyse geçmiş yıllarda elde ettikleri hakları koruma çabalarıdır. 1990’lardan sonra ortaya çıkan farklılıklar kadın hareketinin ilgilendiği konuları zenginleştirmiş olsa da bir taraftan da bütüncül hak taleplerine ket vurmuştur. 2000'lerden sonra ise kadınları geleneksel rollerin dışında görmeyi reddeden bir tavır daha da görünür olmuştur. Bu toplumsal tutumun birçok örneği gazete arşivleri karıştırıldığı vakit görülebilir. Bilindiği üzere, kadının geleneksel rollerinden biri de aile içindeki eş ve annelik konumlarıdır. Bu toplumsal tutum kadınların hak ve özgürlükler bakımından daha da baskı alında kalmalarına neden olmuştur. Söylemlerin gittikçe daha eril bir yapıya büründüğ̈ ve "toplumsal cinsiyet" kavramının bile tartşılmakta olduğu şu günlerde, her ne kadar projeler ile - ki bu projelerin de sürdürülebilirliği en tartısmalı konulardan biridir - tek tek kadın örgütleri, mağdur kadınların hayatlarında bir iyileştirme ve kadınlar için bir güçlendirme çabası içinde olsa da kadınların insan haklarındaki gelişmelerin yavaşladığı bir noktaya vardığımızı söylemek yanlış olmaz.

Bilindiği gibi, Kadınlara Karşı Her Türlü Ayrımcıllı̆ın Önlenmesi Sözleşmesi’ni (CEDAW) Türkiye 1985 yllinda imzalamıs ve bu bağlamda da sözleşmenin, taraf devletlerin toplumsal cinsiyet eşitliğini garanti altına almaya taahüt ettikleri 1. ve 2. Maddelerini kabul etmiştir. ${ }^{4}$ Fakat 2015 Dünya Ekonomik Forumu'nun yayınladığı Küresel Toplumsal Cinsiyet Uçurumu Raporuna göre, ${ }^{5}$ Türkiye toplumsal cinsiyet eşitliği meselesinde 145 ülke arasında 130. sıradadır. Bu durum yaklaşık 100 yıllık bir Cumhuriyet olan Türkiye'nin itibarını toplumsal cinsiyet eşitliğinin bir politika olarak belirlendiği uluslararası arenada zedelemekle kalmamakta, aynı zamanda toplumsal refahı bozmakta ve kadınların her alanda eşit temsil ilkesini de sarsmaktadır.

Sancar'ın (2011: 103) belirttiği gibi, "kadın haklarını yeterli düzeyde koruyabilecek sivil, siyasal ve kamusal mekanizmalara hala sahip değiliz; her adım geriye gitmeye eğilimli, her aygıt kırılgan; kadın örgütlerinin sorun haline getirmediği hiçbir konu kamuoyu gündemine giremiyor ve kendiliğinden çözülmüyor; sivil ve siyasal toplumun refleksleri arasında kadınların ve erkeklerin eşit olması gereği hala yeterince yerleşmemiş" durumdadır ve son kertede kamuoyunun en çok tepki verdiği kadın cinayetleri meselesinde, hala her sene yüzlerce kadın korunma talebi ile yetkililere başvurdukları halde, çoğunlukla beraber oldukları erkekler tarafindan öldürülmektedir. ${ }^{6}$ Örneğin,

\footnotetext{
${ }^{4}$ https://humanrightscenter.bilgi.edu.tr/media/uploads/2015/08/03/KadinlaraKarsiAyrimciliginOnlenmesiSozlesmesi. pdf

${ }^{5}$ http://www3.weforum.org/docs/GGGR2015/cover.pdf

${ }^{6} 2019$ yllında 474 kadın öldürülmüştür. Yıllara göre kadın cinayetleri verilerine http://kadincinayetlerinidurduracagiz.net/kategori/veriler web sitesinden ulaşabilirsiniz.
} 
Kuloğlu, C. (2020). Türkiye'de kadın hareketinin kurumsallaşma süreci. Journal of Human Sciences, 17(1), $324-339$. doi:10.14687/jhs.v17i1.5949

2017 verilerine baktığımızda, Avrupa ülkelerinde partnerleri tarafindan öldürülen kadın sayısı Türkiye'ye nazaran oldukça düşüktür. ${ }^{7}$ Bu bağlamda, kadınlar sadece toplumsal hayata katılmada geri kalmıyor, aynı zamanda en temel insan hakkı olan "yaşama hakkı" da kadınların elinden alınmış oluyor. Başka bir ifade ile, bunca yıllık mücadeleye rağmen, kadınların insan hakları meselesi hala çözüme muhtaç alanlar barındırmaya devam ediyor.

\section{Kaynakça}

Abadan Unat, Nermin. 1998. "Söylemden Protestoya: Türkiye'de Kadın Hareketlerinin Dönüşümü.” 323-336, 75 Yılda Kadınlar ve Erkekler içinde der. A. Berktay Hacımirzaoğlu. İstanbul: Tarih Vakfi Yayınları.

Abadan Unat, Nermin. 1979. “Toplumsal Değişme ve Türk Kadını.” 1-32 Türk Toplumunda Kadın içinde der. N. Abadan Unat. Ankara: Türk Sosyal Bilimler Derneği Yayını.

Alkan, Türker. 1981. Kadın Erkek Eşitsizliği Sorunu, Ankara: Ankara Ün. SBF Yayınları.

Arat, Necla. 1986. Kadın Sorunu. İstanbul: Say Yayınları.

Arat, Yeşim. 1994. "Toward a Democratic Society: The Women's Movement in Turkey in the 1980s." Women's Studies International Forum. Vol. 17(2-3): 241-248.

Berktay, Fatmagül. 1994. Türkiye'de Kadın Hareketi Tarihsel Bir Deneyim. Kadın Hareketinin Kurumsallaşması. İstanbul: Metis Yayınları.

Berktay, Fatmagül. 1998. "Cumhuriyet'in 75 Yillık Serüvenine Kadınlar Açısından Bakmak.” 1-11, 75 Yılda Kadınlar ve Erkekler içinde der. A. Berktay Hacımirzaoğlu. İstanbul: Tarih Vakfı Yayınlar1.

Çilingiroğlu, Nesrin. 2001. "Türkiye'de Akademik Düzeyde Kadına Yönelik Kurumsallaşma." Hacettepe Toplum Hekimliği Bülteni. 20 (2).

Gökalp, Ziya. 1996. Türkçülüğün Esasları, İstanbul: Kamer Yayınları.

Kadın Eserleri Kütüphanesi ve Bilgi Merkezi Vakfi. 1994. Kadın Hareketinin Kurumlaşması: Fırsatlar ve Rizikolar, İstanbul: Metis Yayınlar1.

Kandiyoti, Deniz. 2011. “Türkiye'de Toplumsal Cinsiyet ve Kadın Çalışmaları.” 41-60, Birkaç Arpa Boyu... 21. Yüzyıla Girerken Türkiye'de Feminist Çalışmalar: Prof. Dr. Nermin Abadan Unat' Armağan içinde der. S. Sancar. Ankara: KASAUM.

Kılıç, Zuhal. 1998. "Cumhuriyet Türkiye'sinde Kadın Hareketlerine Genel Bir Bakış." 347-360, 75 Yılda Kadınlar ve Erkekler içinde der. A. Berktay Hacımirzaoğlu. İstanbul: Tarih Vakfı Yayinları.

Koray, Meryem. 2011. “Avrupa Birliği ve Türkiye’de 'Cinsiyet' Eşitliği Politikaları: Sol Feminist Bir Eleştiri." Çalışma ve Toplum 0(2): 13-54.

Kuloğlu, Ceyda. 2017. "Never Ending Nightmare: Violence against Women in Turkey.” International Journal of Multidisciplinary Thought. 06(01): 213-220.

Nizam, Feyzan. 1993. 1980'li Yıllarda Türk Sinemasında Kadın ve Toplumsal Dayanakları. (Yayınlanmamış Yüksek Lisans Tezi), İstanbul: İstanbul Üniversitesi Sosyal Bilimler Enstitüsü.

Ortaylı, İlber. 1984. Osmanlı Toplumunda Aile. Ankara: Türk Sosyal Bilimler Derneği Yayınları.

Sancar, Serpil. 2011. "Türkiye'de Kadın Hareketinin Politiği: Tarihsel Bağlam, Politik Gündem ve Özgünlükler.” 61-104, Birkaç Arpa Boyu... 21. Yüzyıla Girerken Türkiye'de Feminist Çalışmalar: Prof. Dr. Nermin Abadan Unat' Armağan içinde der. S. Sancar. Ankara: KASAUM.

Sirman, Nükhet. 1989. "Feminism in Turkey: A Short History." New Perspectives on Turkey, 3: 1-34.

Süllü, Nur. 1988. Sinemada Feminist Eleştiri. (Yayınlanmamış Yüksek Lisans Tezi), Eskişehir: Anadolu Üniversitesi Sosyal Bilimler Enstitüsü.

Tekeli, Şirin. 1998. "Birinci ve İkinci Dalga Feminist Hareketlerin Karşılaştırmalı İncelemesi." 337 346, 75 Yılda Kadınlar ve Erkekler içinde der. A. Berktay Hacımirzaoğlu. İstanbul: Tarih Vakfi Yayınları.

\footnotetext{
${ }^{7}$ https://www.bbc.com/turkce/haberler-dunya-49633881
} 
Kuloğlu, C. (2020). Türkiye'de kadın hareketinin kurumsallaşma süreci. Journal of Human Sciences, 17(1), $324-339$. doi:10.14687/ihs.v17i1.5949

Tekeli, Şirin. 1988. Kadınlar İçin. İstanbul: Alan Yayıncılık.

Tekeli Sirin. 1986. "The Emergence of the Feminist Movement in Turkey." 179-199, The New Women's Movement içinde der. D. Dahlerup. London: Sage Publications.

Tekeli, Şirin. 1982. Kadınlar ve Siyasal Toplumsal Hayat. İstanbul: Birikim Kitapları.

Timisi, Nilüfer ve Meltem, Ağduk Gevrek. 2002. “1980’ler Türkiye'sinde Feminist Hareket: Ankara Çevresi." 13-39, 90’larda Türkiye'de Feminizm içinde der. A. Bora ve A. Günal. İstanbul: İletişim Yayınları.

Yapar Gönenç, Aslı. 2012. “Fransa’da ve Türkiye’de Kadın Hareketleri.” İstanbul Üniversitesi İletişim Fakültesi Dergisi, 0 (27): 63-84.

\section{Extended English Summary}

The 1980s were a period of accelerated compared to previous years the women's movement in Turkey. Although the women's movement and institutionalization process is close to perfect, review the historical background of the women's movement in Turkey is still important for future studies. The reason is that most of the studies can remain in the descriptive study dimension because they do not touch on the previous period of the women's movement. In addition to this, the women's movement in Turkey since 2000s would not be wrong to argue that a kind of pause period. The purpose of this compilation study in this context is using the historical background to shed light on current studies and reveals the historical roots of the institutionalization of the women's movement in Turkey in order to develop new strategies for current feminist politics.

In explaining the development of the women's movement in Turkey are different periodization studies. Some of these are 3 periods as Sirman (1989), (a) Ottoman Period (b) First periods of the Republic (c) 1980s. According to Tekeli (1986), (a) before Tanzimat (b) Tanzimat Period (c) First years of the Republic and single-party regime time (d) from 1950 to today. Finally, according to Nizam (1993), there are three periods: (a) before the War of Independence (b) After the War of Independence (c) After 1980.

Although different studies periodization of the women's movement in Turkey usually proclamation of the Republic of the point they had reached a consensus on this issue of workers and / or of the Kemalist reforms is that began long ago. The development of women's movement in Turkey has been differentiated according to the position of women in society in this study. In this context, all show a background with the efforts made to present a periodization of the pre-Islamic and development process is examined in chapter five of the women's movement in Turkey:

1. The Position of Women in the Pre-Islamic Society

2. The Position of Women after Islam and in Ottoman Empire

3. The Position of Women in Society in the Republican Period

4. The Position of Women in the 1980s and 1990s

5. Women's Movement in Turkey in 2000s

It is understood from the sources that monogamous marriage rules that women were not excluded from social life in Turkish communities before Islam and that women had equal rights in the family (Tekeli 1982: 192-193). Equality between men and women was one of the most important principles in ancient Turks. Women could have the right to use the goods, as well as the vitalities and zemas. In addition, in ancient Turks, mother and father lines are equally valuable (Gökalp 1996: 165-167).

"In Turkish society, the importance given to women in various periods and the position of women in society have changed. While women have equal rights and positions in the Turkish society before the adoption of Islam, after the adoption of Islam, the woman was reduced to the 
position of 'second-class citizen' by the influence of the religion of Islam and especially Arab culture "(Yapar Gönenç 2012: 71).

When the Tanzimat movement started to develop within the Ottoman State, women started to demand political and social rights with this westernization movement. It can be said that claims for women in the fields of law, politics, education, work, religion and science started in this period (Yapar Gönenç 2012: 74). It is seen that the changes in the Tanzimat period are not limited to new efforts such as fashion, daily life, changes in consumption patterns, learning a foreign language, playing the piano. Structural changes in agriculture, education and education in the 19th century in Ottoman countries began to occur in parallel with the revolution in communication and technology in the world. The reflection of these developments on the Ottoman lands showed itself in the rural areas as well as the city (Ortayli 1984: 85).

Kemalist nationalist cadres under the leadership of the Republic of Turkey was founded after the War of Independence. Even though this war proved that women were able to take on the duties of men successfully, it did not make a radical change in the traditional roles of women. As stated by Berktay (1994: 26), "Turkish culture is a culture that legitimates patriarchal values that legitimize male domination and adopts the sexual division of labor that keeps women 'in their place' without question and as can be easily guessed, 'the place of women' is not adopted by women themselves.

Participation of women in political life and gaining their political rights was realized with a delay. Firstly, they exercised their election and election rights in the municipal elections in 1930, and were able to participate in general elections in 1934. As in other countries, women did not fight to achieve these rights, and these rights were given to them. It is thought that the granting of these rights is made for the purpose of modernization rather than thinking about women (Tekeli 1988: 74-75). In other words, it would not be wrong to say that all developments for women are used in a way to be compatible with the West and show the world how modern we are.

In the 1980s, especially the women's movement started by questioning the distinction between the public and private spheres in a political struggle axis. This beginning, summarized by the slogan "the personal is political", included the agenda of the second generation western women, but with one difference, the periods were different. In the 1960s western women use this slogan could be moved to Turkey in 1980. The second generation of women is defined as the movement from 1980-1990 in Turkey to discuss the existential problems of being a woman for women, gender and feminism evident that the meaning of femininity has been a period of discussion as a social project. The most appropriate concepts describing this period can be described as "awareness raising", "strengthening" and "creating sensitivity" (Timisi and Ağduk Gevrek 2002: 14-15). In the beginning of the 1990s, some of the women's associations that were opened in the 80 s were closed, and non-organizing groups were dispersed. It is obvious that the initial enthusiasm and excitement cannot be expected to continue at the same level. However, in this decade of women's movement, there seems to be a tendency towards institutionalization (Kılıç 1998: 357).

Turkey in particular women's movement when we look at the developments in the 2000s, shows the gender equality policy has entered a period of decline compared to previous years. In this period, it is seen that the gender equality debates were replaced by the position of the woman in the family with the effect of the studies in the government. Today, it is undeniable stagnation and even found the women's movement in Turkey has entered a period of decline is real. Although it has a legacy of those years, arrived at the point where they are almost protection of women's rights in Turkey today they have obtained in the past years efforts. Although the differences that emerged after the 1990s enriched the issues that the women's movement was interested in, it also prevented the holistic claims. The general political attitude after the 2000s is an attitude that refuses to see women outside their traditional roles. It would not be wrong to say that we have reached a point where the developments in women's human rights have slowed. 